\title{
In silico diabetológia
}

\author{
Dió Mihály - Deutsch Tibor dr. - Mészáros Judit dr.
}

Semmelweis Egyetem, Egészségtudományi Kar, Budapest

\begin{abstract}
Bevezetés: A különböző szimulációs modellek jelentôs segítséget nyújthatnak a cukorbetegekben zajló folyamatok megértéséhez és szabályozásához. Célkitüzés: A szerzők egy átfogó, élettani megalapozottságú szimulációs modell körvonalait mutatják be. Módszer: A modell glükóz-, inzulin- és glükagonrészmodellekből épül fel. Eredmények: A glükózmodell a glükózfelszívódás dinamikáját, a máj glükóztermelését és -felvételét, a perifériás szövetek glükózfelvételét, a vesén keresztül történő kiválasztást, továbbá az agy és vörösvérsejtek glükózfelhasználását írja le. Az inzulinmodellben az inzulin felszívódására, a béta-sejtek inzulinelválasztására és az inzulin eliminációjára vonatkozó egyenletek kapnak helyet. A glükagonmodellben a hormon szekrécióját és eliminációját megfogalmazó összefüggések szerepelnek. A szénhidrátanyagcsere-modellben algebrai egyenletek írják le, hogy az inzulin- és glükagonszintek miként befolyásolják a glükóztermelést és -felhasználást, továbbá azt, hogy a glükózszintek emelkedése milyen hatást gyakorol az inzulin és glükagon kiválasztására. Következtetések: A paraméterek értékének változtatásával a modell lehetővé teszi tetszőleges virtuális inzulinfüggő és nem inzulinfüggő cukorbetegek szimulálását. Orv. Hetil., 2016, $157(6), 219-223$.
\end{abstract}

Kulcsszavak: vércukor, inzulin, diabetes, modell, szimuláció

\section{In silico diabetology}

Introduction: Simulation models can contribute substantially to our understanding and ability to control the dynamic processes underlying impaired glucose metabolism in diabetic patients. Aim: The aim of this paper is to outline a new comprehensive, physiologically-based dynamic model of glucose homeostasis incorporating up-to-date quantitative knowledge about glucose metabolism and its control by insulin and glucagon. Method: The model is composed of three submodels for glucose, insulin, and glucagon. Results: The glucose submodel specifies the dynamics of glucose absorption following meals, hepatic glucose production and uptake, peripheral glucose uptake, kidney excretion, and insulin-independent uptake of glucose in the brain and red blood cells. The insulin submodel includes equations for insulin absorption, pancreatic insulin release and insulin clearance. The glucagon model specifies the hormone secretion and elimination kinetics. Algebraic equations are used to specify (i) how the hormones affect glucose production and utilisation in various compartments such as liver, muscle and fat tissues, and (ii) how glucose levels modify insulin and glucagon release from the pancreas. Setting the values of various model parameters is used to generate virtual individual patients. Conclusions: The model allows the simulation of 24-hour blood glucose profiles for both insulin-dependent non-insulin dependent diabetic patients.

Keywords: blood glucose, insulin, diabetes, model, simulation

Dió, M., Deutsch, T., Mészáros, J. [In silico diabetology]. Orv. Hetil., 2016, 157(6), 219-223.

(Beérkezett: 2015. november 19.; elfogadva: 2015. december 15.)

\section{Rövidítések}

AIDA = automated insulin dosage advisor; IDDM = inzulinfüggő cukorbetegség; NIDDM = nem inzulinfüggő cukorbetegség; PK-PD = farmakokinetika-farmakodinamika

A plazma glükózkoncentrációját egészséges állapotban komplex szabályozási folyamatok tartják egy szúk tarto- mányban. Az abszolút vagy relatív inzulinhiány l-es típusú inzulinfüggő (IDDM), illetve 2-es típusú nem inzulinfüggő (NIDDM) cukorbetegség kialakulásához vezet. A betegség hátterében alapvetően a hasnyálmirigy, máj és perifériás (zsír- és izom-) szövetek abnormális múködése húzódik meg. A különböző múködési zavarok az egyes betegekben eltérő mértékben és kombinációban jelennek meg. 
Az egyénre szabott optimális terápia beállítása gyakorta nehézségekbe ütközik annak ellenére, hogy a diabetes menedzselésére számos gyógyszer és különböző hatásidejü inzulinkészítmény áll rendelkezésre. A gondozási terv elkészítésénél jelentős segítséget jelentene, ha a jelenleginél sokkal finomabb, kvantitatív módszerekkel tudnánk jellemezni a beteg állapotát, és előre tudnánk becsülni a szóba jövő terápiák várható hatásait. Ennek a lehetőségét teremti meg az in silico medicina (esetünkben az in silico diabetológia), amely várhatóan alapjaiban fogja átformálni a gyógyítás jelenlegi gyakorlatát [1].

Az in silico medicina alapvető szereplői az úgynevezett digitális páciensek, amelyek a valódi betegek dublőrjei a gyógyítási folyamatban [2]. Ezek a virtuális páciensek a betegek olyan valósághú elektronikus másolatai, amelyekkel a betegek viselkedését előre lehet jelezni és anélkül lehet meghatározni a szükséges tennivalókat, hogy a valódi beteget szükségtelen kockázatoknak tennénk ki.

A diabetológiában a digitális páciensek előfutárai azok a különböző számítógépes szénhidrátanyagcsere-modellek és -szimulátorok, amelyeket az utóbbi években gyakran használtak a betegek oktatásában és klinikai menedzselésében egyaránt. A modellek típusa, matematikai megfogalmazása és bonyolultsága rendkívül széles spektrumot ölel fel [3].

A spektrum egyik szélén az úgynevezett minimális modellek találhatók, amelyek elsősorban a különböző glükózterheléses vizsgálatok kvantitatív értékelését segítik. A spektrum másik szélén helyezkednek el a biokémiai és élettani részleteket is tartalmazó dinamikus modellek.

Noha a vércukor-szabályozásban számos metabolit és hormon vesz részt, a legtöbb modell a glükóz és inzulin szerepére fókuszál [4]. Leggyakoribbak a különbözó kompartmentummodellek, amelyekben az egyes kompartmentumok a különböző szerveknek és szöveteknek felelnek meg [5]. A Sorensen-modellt a közelmúltban NIDDM-páciensekre is adaptálták [6]. Sun és mtsai a metformin részletes farmakokinetikai-farmakodinamikai (PK-PD) modelljéról számoltak be [7].

Munkacsoportunk hosszabb ideje fejleszti az úgynevezett AIDA (automated insulin dosage advisor) interaktív, oktatási célú diabetesszimulációs modellt $[8,9]$. A szimulátor segítségével a felhasználók tetszőleges számban generálhatnak virtuális betegeket, és megnézhetik, hogy különböző diéta, testmozgás és inzulinkezelés mellett miként alakul a virtuális betegek napi vércukorprofilja. $\mathrm{Az}$ interneten is elérhető program azonban idővel kissé elavult, hiszen kizárólag IDDM-cukorbetegeket tud szimulálni, nem tartalmazza a korszerü inzulinanalóg készítményeket és orális antidiabetikumokat sem. A közelmúltban egy rövid beszámoló jelent meg az AIDA-modell továbbfejlesztéséről és kibővítésérôl [10].

Jelen közleményünkben egy átfogó, élettani megalapozottságú szimulációs modell körvonalait mutatjuk be, amely egyaránt alkalmas IDDM- és NIDDM-páciensek 24 órás vércukorprofiljának predikciójára megadott dié- ta, fizikai aktivitás, tablettás és/vagy inzulinkezelés mellett. A szénhidrátanyagcsere-szimulátor múködését példák segítségével illusztráljuk.

\section{Módszer}

A cukorbetegekben zajló különböző transzport- és metabolikus folyamatokat egy élettani megalapozottságú kompartmentummodell segítségével írtuk le. A modellben szereplő differenciál- és algebrai egyenletek a glükóz, inzulin és glükagon transzportját, megoszlását és a köztük zajló kölcsönhatásokat fogalmazzák meg a különböző szervekben és szövetekben, matematikai alakban. A modell grafikus sémáját az 1 ábra szemlélteti.

A szénhidrát-anyagcsere alapvető folyamatait az ábra bal oldalán ábrázoltuk, míg az ábra jobb oldalán a keringési rendszer sémája látható. A szénhidrát-anyagcserében fontos szerepet játszó valamennyi szervnek (agy, máj, szív/tüdő, periféria, bél, vese és pancreas) egy külön kompartmentum (téglalap) felel meg. A nyilak a véráramlás irányát mutatják $\mathrm{Az}$ utóbbi blokkséma alapján fogalmaztuk meg a modell anyagmérleg-egyenleteit. Ezek segítségével tudjuk kiszámítani, hogy a glükóz és a két hormon szintje miként alakul a különböző szervekben az idő függvényében.

A teljes modell a glükóz-, inzulin- és glükagonrészmodellekból épül fel. A glükózmodell a glükózfelszívódás dinamikáját, a máj glükóztermelését és -felvételét, a perifériás szövetek glükózfelvételét, a vesén keresztül történő kiválasztást, továbbá az agy és vörösvérsejtek glükózfelhasználását leíró összefüggésekből áll. Az inzulinmodellben a subcutan inzulininjekciókat követő felszívódásra, a béta-sejtek inzulinelválasztására és az inzulin kiürülésére vonatkozó összefüggések kapnak szerepet. A glükagonmodell a hormon szekrécióját és eliminációját írja le. A modellben különböző algebrai egyenletek fogalmazzák meg, hogy hormonok (inzulin és glükagon) miként befolyásolják a glükóztermelést és -felhasználást, továbbá azt, hogy a glükózszint emelkedése milyen hatást gyakorol az inzulin és glükagon szekréciójára.

Az orális antidiabetikumok közül jelenleg egyedül a metformin PK-PD modellje kapott helyet az egyenletek között. A PK-modellben a metformin három kompartmentum (bél, máj és periféria) között oszlik meg, a PDmodell egyenletei pedig azt fogalmazzák meg, hogy a metformin miként fokozza a glükózfelhasználást a bélben és a glükóz felvételét a zsír- és izomszövetekben, továbbá hogyan csökkenti a máj glükóztermelését.

\section{Virtuális páciensek generálása}

A szénhidrát-anyagcsere modellje egy generikus leírást kínál, amelyben nagyszámú paraméter (például inzulinérzékenység, megoszlási terek nagysága stb.) található. A paraméterek jellemző átlagértékeit a szakirodalomból határoztuk meg. 


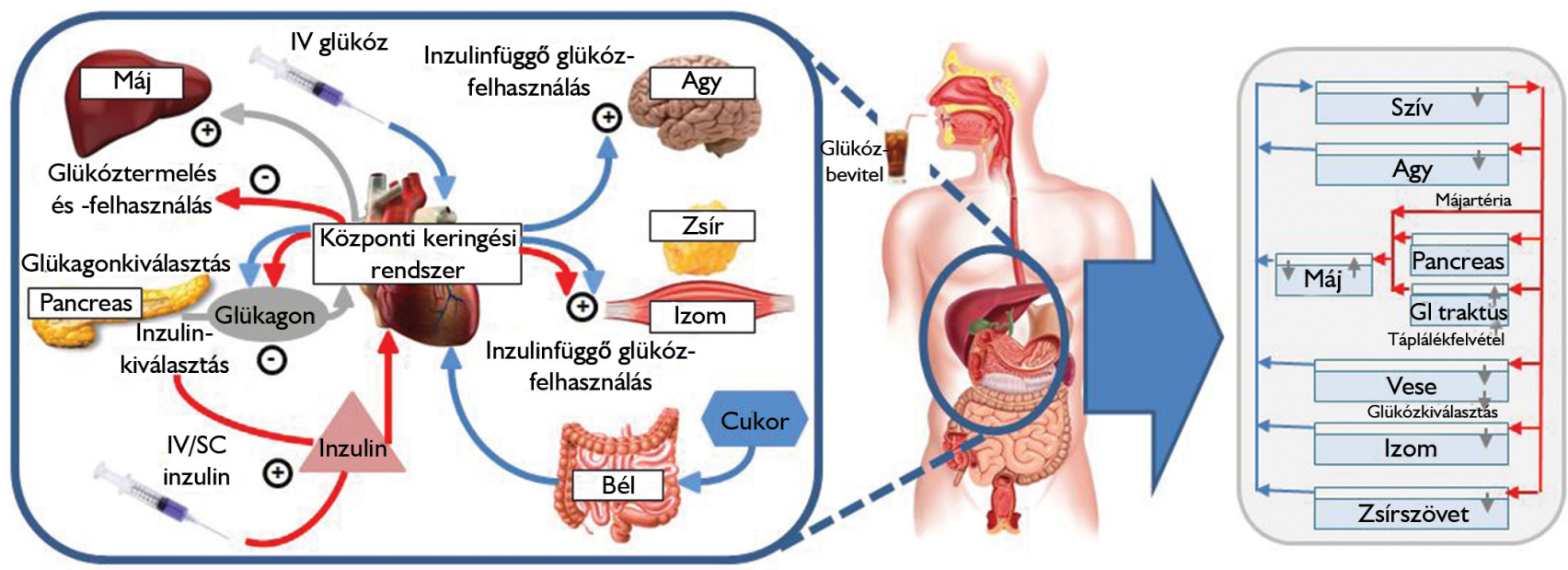

1. ábra

| A szénhidrát-anyagcsere alapvető folyamatai és a keringési modell sémája

A modellben számos olyan paraméter szerepel, amelyek a különböző szervek funkcionális károsodásának a mértékét fejezik ki. IDDM-pácienseknél például a pancreas egyáltalán nem reagál a vércukorszintek emelkedésére, elhízott betegeknél pedig a perifériás inzulinérzékenység jellemzően jóval alacsonyabb az átlagosnál. Az egyéni eltéréseket tehát a jellemző paraméterek értékének megfelelő beállításával lehet specifikálni.

Az egyéni változékonyság természetesen az életmódban (például étkezések) is megjelenik, és a paraméterek értékének beállításával a vizsgált szituáció külső körülményeit is modellezni lehet. Az elfogyasztott ételek glykaemiás indexének változtatásával például a glükózfelszívódás ütemét lehet módosítani.

\section{Implementáció}

A szimulációs modellt a Berkeley Madonna program (www.berkeleymadonna.com) segítségével implementáltuk. A modell egyes részeit az AIDA for Windows program próbaverziójával teszteltük.

\section{Eredmények}

A szénhidrátanyagcsere-modell használatát néhány példa segítségével illusztráljuk. A következő példák egyben azt is szemléltetik, hogy a dinamikus modellt milyen típusú kérdések megválaszolására lehet használni.

A szimulációs modellek kézzelfogható előnye, hogy segítségükkel olyan folyamatok részleteibe is bepillantást nyerhetünk, amelyeket kísérleti úton nehéz és/vagy igen költséges nyomon követni.

A 2. ábrán 20 E különböző típusú inzulinkészítmény subcutan beadását követően kialakuló plazmaszinteket ábrázoljuk az idő függvényében. A plazmaszintek kiszámításához az inzulinfelszívódás és megoszlás/elimináció modelljeit kell figyelembe venni.

A szimulációs modellek alapvető szerepet játszanak a „mi lenne, ha...” típusú kérdések megválaszolásában.
Gyakori kérdés például, hogy milyen (hypoglykaemiás) kockázatokkal kell számolnunk akkor, ha a beteg kihagy egy föétkezést, vagy véletlenül 10 E-gel több gyors hatású inzulint ad be magának. Tipikus helyzet az is, amikor a szóba jövő alternatív terápiák (például különböző tablettás [metformin] és inzulinkezelések) hatásait szeretnénk összehasonlítani egymással. A 3. ábrán egy ilyen összehasonlító szimuláció eredményét szemléltetjük.

Jól látható, hogy a kombinált terápiák esetében alacsonyabb vércukorszinteket érhetünk el, mint a monoterápiákkal. Ugyanakkor a két monoterápia közül az inzulin adása a hatékonyabb. A kombinációs terápiák esetében nem figyelhetők meg lényeges eltérések, ha a bazális inzulint és a metformint eltérő dózisokban alkalmazzuk.

Végül a szimulációs modell jó szolgálatot tesz különböző vércukor-beállítási problémák megoldásában is. Egy ilyen szituációt szemléltetünk a 4. ábrán. Az ábra

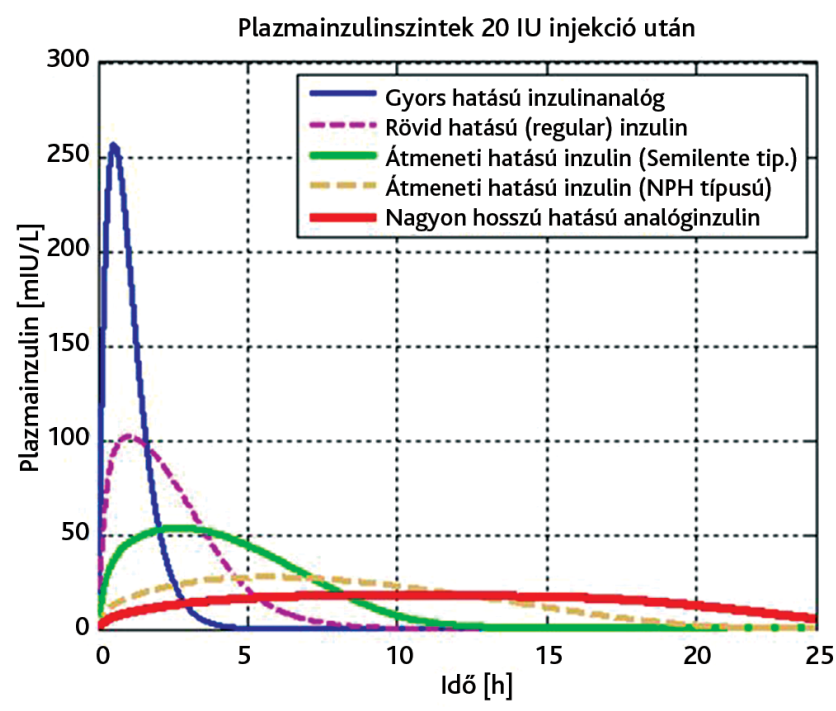

2. ábra $\quad$ A plazmainzulinszintek időbeli alakulása különböző típusú in zulinkészítmények subcutan injektálását követően 




3. ábra | Alternatív terápiák hatása a vércukorszintre

felső paneljén egy beteg szimulált napi vércukorprofilját kísérhetjük nyomon. A középső panelen az alkalmazott inzulinkezelés sémája (bazál + bólus) szerepel. Ugyanezen a panelen az alkalmazott inzulinterápia során kialakuló szimulált plazmainzulinszintek is leolvashatók. $\mathrm{Az}$ alsó panelen a napi szénhidrátbevitel időpontjai és az elfogyasztott adagok láthatók. A felsô panelen futó kék színú görbén jól látszik, hogy az esti órákban a beteg vércukorértékei a hyperglykaemiás tartományba kerültek. Az ábra jól szemlélteti, hogy ezt a hyperglykaemiát a vacsora előtt adott gyors hatású inzulin adagjának növelésével könnyen megszüntethetjük (fekete görbe).

A kidolgozott szimulációs modell segítségével kapott eredmények összhangban vannak a szakirodalomban található kísérleti és klinikai adatokkal. A modell szisztematikus validálása a közeljövő feladata.



Plazmainzulin $(\mathrm{mU} / \mathrm{l})$

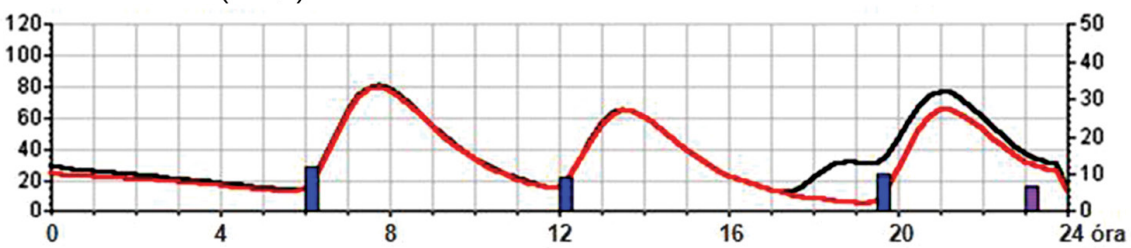

Szénhidrátbevitel $(\mathrm{g})$

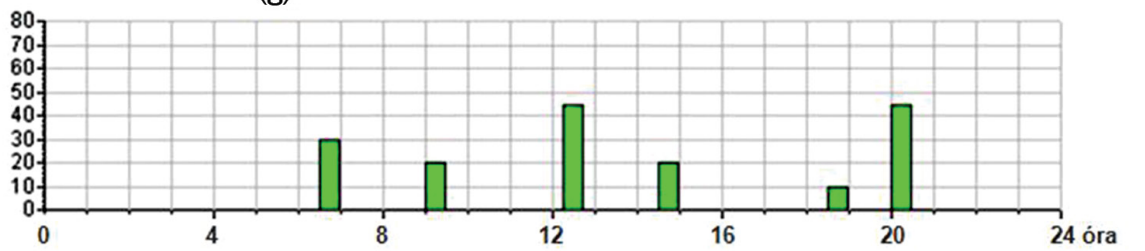

4. ábra $\quad$ Az esti hyperglykaemia korrekciójának szimulációja az AIDA for Windows program környezetben [9]

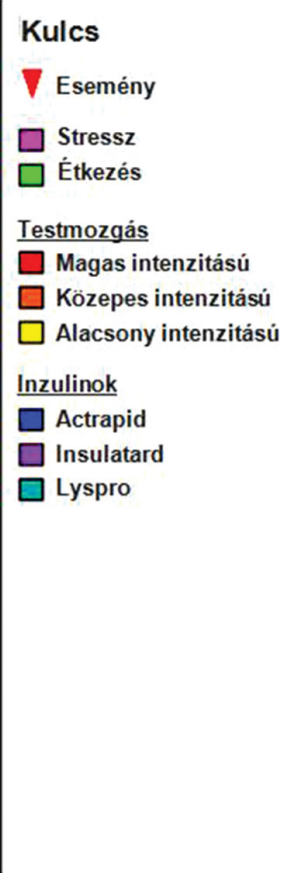




\section{Megbeszélés}

Közleményünkben egy átfogó, dinamikus glükózanyagcsere-modellt mutattunk be, amely egyaránt képes szimulálni IDDM- és NIDDM-cukorbetegek viselkedését. Az új modell felépítésénél elsősorban Sorensen (1985), Vabidi és mtsai (2011), Sun és mtsai (2011), valamint Lehmann és mtsai (2007) munkáira támaszkodtunk, és három elvet tartottunk szem előtt. Az első elv szerint mindvégig az egyszerüségre törekedtünk: A modellben nem szerepelnek olyan részletek, amelyek a napi vércukorprofilok megbízható előrejelzéséhez nem feltétlenül szükségesek. A második elv értelmében a modell „építményét” legószerü elemekből igyekeztünk összerakni. Ez a moduláris szerkezet az előfeltétele annak, hogy a modellt könnyen lehessen módosítani és bővíteni. A harmadik elv tiltja a fiktív kompartmentumok használatát. Más szavakkal, a modellben csak olyan kompartmentumok és paraméterek szerepelhetnek, amelyekhez pontos élettani jelentést tudunk társítani. Ebből következik, hogy a modell szimulációja során nem csupán a vércukor- (és plazmainzulin-) szintek időbeli alakulását követhetjük nyomon, hanem részletes képet kaphatunk az egyes szervekben lezajló transzport- és metabolikus folyamatok időbeli dinamikájáról is.

Nagyon lényeges, hogy a modellben szereplő valamennyi paraméter világos anatómiai és élettani jelentéssel bír. Ennek köszönhetően a cukorbetegeket a mostaninál jóval finomabban tudjuk jellemezni. A szokásos egyetlen inzulinérzékenység helyett a modellben külön paraméterekkel jellemezzük az inzulin hatását a májban és a zsír/izom szövetekben. Ezek megfelelő beállításával aszerint tudunk generálni virtuális betegeket, hogy a magas vércukorértékek hátterében elégtelen hepaticus vagy perifériás inzulinhatás húzódik-e meg. A finomított diagnózis egyben megkönnyíti azt is, hogy az életmódot, gyógyszeres vagy inzulinterápiát az adott beteg sajátosságaihoz illesszük (személyre szabott medicina).

A modell jelenlegi állapotában korántsem teljes. A jelenlegi változatból még hiányzik a fizikai aktivitás és stressz pontos leírása, és a gyógyszerpalettán egyedül a metformin árválkodik. A legóstruktúrának köszönhetően a modell bővítésekor csupán azt kell rögzítenünk, hogy az új ágensek (például egy szulfanilureakészítmény) melyik modell paraméterértékét befolyásolják, és a szakirodalom alapján meg kell határoznunk ennek a kapcsolatnak a pontos matematikai alakját.

\section{Következtetések}

A szimulációs modell segítségével tetszőleges in silico pácienseket generálhatunk és megvizsgálhatjuk, hogy ezek miként viselkednek különböző életmód és terápia mellett. A szimuláció segítségével mélyebb betekintést nyerhetünk a cukorbetegekben zajló anyagcsere-folyamatok dinamikájába. A hasonló rendszerekkel szerzett tapasztalatok szerint a szimulációs modellek hatékonyan használhatók a betegedukációban, az orvostovábbképzésben és nem utolsósorban a krónikus gondozás során felmerülő beállítási problémák megoldásában (döntéstámogatás). Az új modellt a széles körú használatot megelőzően azonban feltétlenül validálni kell és egy olyan grafikus interfésszel kell ellátni, amelyen keresztül a felhasználók könnyen kommunikálni tudnak a számítógépes szimulátorral. A szimulációs modell az in silico medicina és digitális páciens törekvések sorába illeszkedik, és fontos lépést jelent az in silico diabetológia irányába.

Anyagi támogatás: A közlemény megírása, illetve a kapcsolódó kutatómunka anyagi támogatásban nem részesült.

Szerzői munkamegosztás: D. M.: A kézirat megszövegezése. D. T.: Elemzések. M. J.: Tanácsadó. A cikk végleges változatát mindhárom szerző elolvasta és jóváhagyta.

Érdekeltségek: A szerzőknek nincsenek érdekeltségeik. A kézirat Dió Mihály PhD-kutatásához kapcsolódik, amelynek témavezetője Dr. Deutsch Tibor.

\section{Irodalom}

[1] Dimitrov, D. V.: Systems patientomics: the virtual in-silico patient. EPMA J., 2014, 5(Suppl. 1), A53.

[2] Diaz, V., Viceconti, M., Stroetmann, V., et al.: Roadmap for the Digital Patient. http://www.vph-institute.org/upload/discipulus-digital-patient-research-roadmap_5270f44c03856.pdf

[3] Makroglou, A., Li, J., Kuang, $\Upsilon$.: Mathematical models and software tools for the glucose-insulin regulatory system and diabetes: an overview. Appl. Numer. Mathemat., 2006, 56, 559-573.

[4] Dalla Man, C., Raimondo, D. M., Rizza, R. A., et al.: GIM, simulation software of meal glucose-insulin modell. J. Diabetes Sci. Technol., 2007, 1(3), 323-330.

[5] Sorensen, J. T.: A physiologic modell of glucose metabolism in man and its use to design and assess improved insulin therapies for diabetes. Thesis (Sc. D.) - Massachusetts Institute of Technology, Department of Chemical Engineering, Cambridge, 1985.

[6] Vahidi, O., Kwok, K. E., Gopaluni, R. B., et al.: Developing a physiological model for type II diabetes mellitus. Biochem. Engin. J., 2011, 55(1), 7-16.

[7] Sun, L., Kwok, E., Gopaluni, B., et al.: Pharmacokinetic-pharmacodynamic modeling of metformin for the treatment of type II diabetes mellitus. Open Biomed. Eng. J., 2011, 5, 1-7.

[8] Lehmann, E. D., Deutsch, T., Carson, E. R., et al.: AIDA: an interactive diabetes advisor. Comput. Methods Programs Biomed., 1994, 41(3-4), 183-203.

[9] Lehmann, E. D., Tarín, C., Bondia, J., et al.: Incorporating a generic model of subcutaneous insulin absorption into the AIDA v4 diabetes simulator: 1. A prospective collaborative development plan. J. Diab. Sci. Technol., 2007, 1(3-4), 423-435.

[10] Dió, M., Deutsch, T., Mészáros, J.: An educational model of glucose homeostasis in diabetes mellitus. New Medicine, 2014, $18(1), 29-32$.

(Dió Mihály,

Budapest, Vas utca 17., 1088 e-mail:diom@se-etk.hu) 